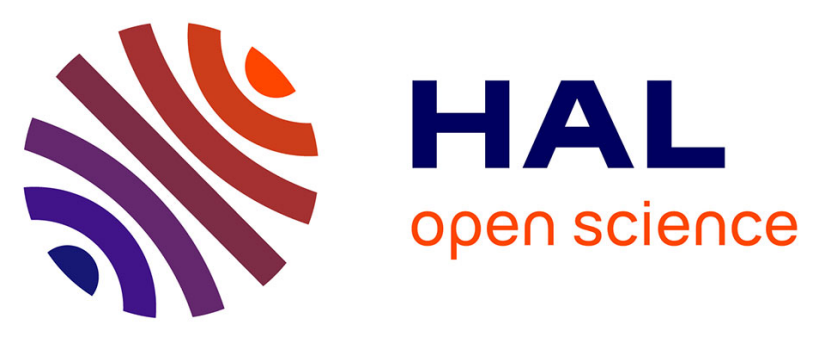

\title{
The reproductive response of the sea urchins Paracentrotus lividus (G.) and Psammechinus miliaris (L.) to an hyperproteinated macrophytic diet
} Anne-Gaelle Jacquin, Anne Donval, Jacques Guillou, Sandra Leyzour, Eric Deslandes, Monique Guillou

\section{To cite this version:}

Anne-Gaelle Jacquin, Anne Donval, Jacques Guillou, Sandra Leyzour, Eric Deslandes, et al.. The reproductive response of the sea urchins Paracentrotus lividus (G.) and Psammechinus miliaris (L.) to an hyperproteinated macrophytic diet. Journal of Experimental Marine Biology and Ecology, 2006, 339, pp.43-54. 10.1016/j.jembe.2006.07.005 . hal-00460554

\section{HAL Id: hal-00460554 \\ https://hal.univ-brest.fr/hal-00460554}

Submitted on 1 Mar 2010

HAL is a multi-disciplinary open access archive for the deposit and dissemination of scientific research documents, whether they are published or not. The documents may come from teaching and research institutions in France or abroad, or from public or private research centers.
L'archive ouverte pluridisciplinaire HAL, est destinée au dépôt et à la diffusion de documents scientifiques de niveau recherche, publiés ou non, émanant des établissements d'enseignement et de recherche français ou étrangers, des laboratoires publics ou privés. 
1 The reproductive response of the sea urchins Paracentrotus

2 lividus (G.) and Psammechinus miliaris (L.) to an

3 hyperproteinated macrophytic diet.

4 JACQUIN Anne-Gaëlle a.b, DONVAL Anne b, GUILLOU Jacques b,

5 LEYZOUR Sandra $^{\mathrm{b}}$, DESLANDES Eric ${ }^{\mathrm{a}}$, GUILLOU Monique ${ }^{\mathrm{b}, *}$.

6

7 a LEBHAM, Université de Bretagne Occidentale, Institut Universitaire

8 Européen de la Mer, Place Nicolas Copernic, 29280 Plouzané, France.

9 b LEMAR, UMR CNRS 6539, Université de Bretagne Occidentale, Institut

10 Universitaire Européen de la Mer, Place Nicolas Copernic, 29280 Plouzané,

11 France.

$13 *$ Corresponding author. Tel: +33-02-9849-8634; fax: + 33-02-9849-8645

14 E-mail address : Monique.Guillou@univ-brest.fr

16 Abstract

18 The sea urchins Paracentrotus lividus and Psammechinus miliaris are

19 submitted to the same environmental conditions in the Bay of Brest. The

20 relationship between seasonal changes in food source quality and their

21 gonad production was investigated in reproducing experimentally these

22 conditions. In a first stage two macroalgae (Palmaria palmata and Laminaria

$23 \underline{\text { digitata) }}$ were tested. $\underline{\text { P. miliaris }}$ showed a stronger preference for $\underline{P}$. palmata

24 and over a year-long experiment both urchins progressively preferred $\underline{\mathrm{P}}$.

25 palmata. Seasonal variations in the chemical composition of P. palmaria 
26 were observed in the Bay of Brest: total carbohydrates were important and

27 the relative maximum (about 50\%) was reached between February and

28 August; the lipid level was low and had a relative maximum of about $1 \%$ in

29 June and August. Total protein in P. palmaria was high compared to other

30 seaweeds: the maximum value (25\%) was observed in June, that was

31 probably due to the maintenance of nitrogen nutrient in the bay.

32 In the second stage of the study, seasonal changes in biochemical

33 components of ingestion and absorption of the two sea urchins were

34 followed in the laboratory using a monospecific diet of $\underline{P}$. palmaria. The

35 patterns of total carbohydrates and lipid absorption were very similar for

36 both sea urchin species. Carbohydrates were absorbed strongly and

37 uniformly, year round. Lipid absorption mimicked the lipid nutrient pattern

38 in the food source. Only changes in protein absorption varied slightly

39 between the two urchin species. Protein absorption was maximal for both

40 species in February and June, but the quantity of absorbed protein was

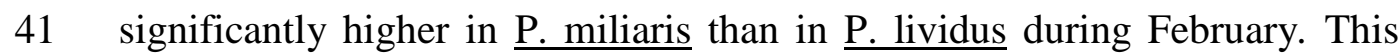

42 increase was concomitant with protein storage in the sea urchin gonads,

43 which peaked in February for $\underline{P}$. miliaris and in June for $\underline{P}$. lividus. $\underline{P}$.

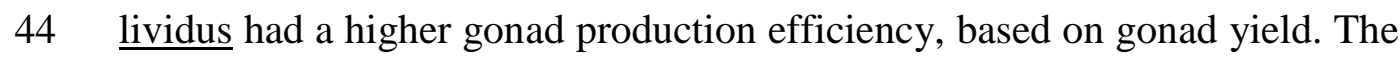

45 comparison between in situ data and the experimental results suggests that

46 an algal diet more nitrogenous than the in situ algal food source would

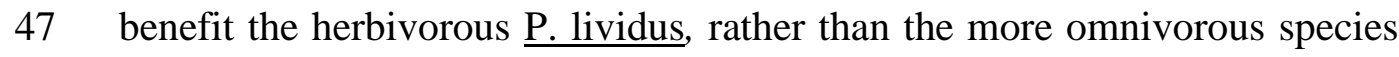

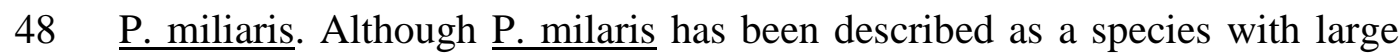

49 gonad production potential, $\underline{\text { P. lividus appears to be a more suitable species }}$

50 for echiniculture conditions. 
52 Key words: sea urchin diet, Palmaria palmata. proximate composition,

53 absorption efficiency, gonadal cycle.

\section{1. Introduction}

57 The sea urchins Paracentrotus lividus (Lamarck) and Psammechinus miliaris

58 (Gmelin) are the two most common sea urchin species on the western coast

59 of Brittany (France). Both species live in sheltered areas of intertidal and

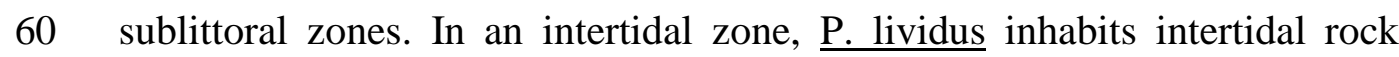

61 pools and $\underline{\text { P. miliaris }}$ lives under boulders; in subtidal zones, $\underline{\text { P. lividus }}$

62 occurs mainly on solid rocks or in seagrass meadows and has been observed

63 on bottom sediments as diverse as gravels, heterogeneous sands or on maerl

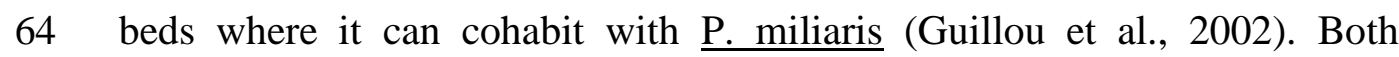

65 species have a commercial value. $\underline{P \text {. lividus populations have dramatically }}$

66 decreased on the northern coasts of Brittany because of destructive

67 harvesting (Allain 1975, Southward and Southward, 1975). Although $\underline{P}$.

$68 \underline{\text { miliaris }}$ is smaller in size than $\underline{P \text {. lividus, }}$, it has a greater gonad production

69 potential (Le Gall et al., 1989). Management of their populations could be

70 improved by echiniculture.

71 Sea urchin biology, in general, has been well-studied all over the world,

72 however studies of urchin populations in western Brittany are rare or

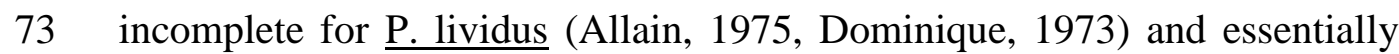

74 for P. miliaris (Le Gall et al., 1989, 1990). Although both species have

75 different areas of geographical distribution, they live in the Bay of Brest 
76 under similar environmental conditions. Their different temperature optima

77 can lead to different patterns of reproductive cycle in the present

78 environment (Guillou, pers.obs.). Moreover, although they are inherently

79 herbivorous, they can have different diet preferences (Boudouresque and

80 Verlaque, 2001; Kelly and Cook, 2001). The purpose of this study is to use

81 these specific differences to analyze the correlation between food quality

82 and pattern of reproductive cycle in sea urchins.

83 In the first stage of our study, their dietary preferences among the

84 macrophytes available in situ were tested by an experimental procedure. Sea

85 urchins from the Bay of Brest were maintained in live under conditions as

86 similar as possible to those of their natural habitat. A monospecific diet was

87 desirable for the second stage of the study in which food ingestion rates and

88 absorption rates were evaluated in terms of three major biochemical

89 components: proteins, lipids and carbohydrates. These results were

90 compared to the status of the sea urchins gonad production throughout a

91 year-long experiment. Our approach combined simultaneous analyses of the

92 seawater nutrients, the natural food source biochemistry and the absorption

93 of different components by each species to explain changes in the gonad

94 yield and composition during an annual cycle. The physiological responses

95 of each species (food ingestion and absorption, reproductive growth) were

96 also measured and compared with the goal of improving the culture of these

97 two sea urchin populations.

98

99 


\section{2. Materials and methods}

101

102 2.1 Sampling and maintenance

103

104 The reproductive cycle of adult Paracentrotus lividus and $\underline{\text { Psammechinus }}$

$105 \underline{\text { miliaris }}$ in the Bay of Brest was investigated from February 1997 to

106 December 1998. The individuals were collected monthly by dredging or

107 SCUBA divers from a site situated in the southern part of the Bay of Brest

108 (Guillou et al., 2002) on substratum covered by maerl (a substrate composed

109 of the living thalli of the calcareous red alga, Lithotamnion corallioides $(\mathrm{P}$.

110 and H. Crouan)). This substratum promotes the development of epiphytic

111 macrophytes assemblages dominated by Rhodophyceae.

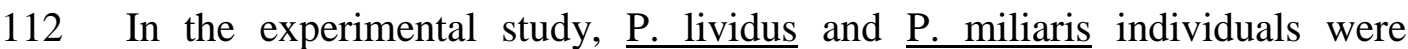

113 collected by dredging in March 2000 in the same site. In the laboratory, the

114 sea urchins were divided into three replicate groups consisting of 10

115 individuals of each species, to measure feeding rates. Additionnal tanks

116 maintained in the same experimental conditions were used for

117 measurements of sea urchin gonad indices and biochemical analyses on the

118 gonad tissues. A homogeneous size-class, representative of the dominant

119 size-class of each population (Guillou et al., 2002), was selected: $\underline{\text { P. lividus: }}$

$120 \quad 32-36 \mathrm{~mm}(34.3 \pm 1.8)$ and $\underline{P . \text { miliaris }} 22-25 \mathrm{~mm}(24.1 \pm 1.5)$. The sea urchin

121 groups were placed in tanks $(60 \times 40 \times 30 \mathrm{~cm})$ supplied with fresh running

122 seawater from the Bay of Brest passed through on a sand-filter at

123 temperatures which ranged from $9{ }^{\circ} \mathrm{C}$ in winter up to $17{ }^{\circ} \mathrm{C}$ in summer. A

124 plastic grid of $2 \mathrm{~mm}$ meshes on the evacuation exit of each tank prevented 
125 the loss of algae or faeces. The photoperiod was adjusted weekly with a

126 timer by means of a set of neon tubes placed directly over the tanks (one 30-

127 watt tube per two tanks). Three replicate groups were used to measure

128 feeding rates.

129 A preliminary test for food preferences for the two species was

130 completed using: two green algae Cladophora rupestris (Linnaeus) Kützing

131 and Enteromorpha ramulosa (Linnaeus), two red algae Palmaria palmata

132 (Linnaeus) O. Kuntze, Solieria chordalis (C. Agardh) J. and Plocamium

133 cartilagineum (Linnaeus) P. Dixon, and two brown algae Laminaria digitata

134 (Hudson) Lamouroux and Bifurcaria bifurcata (Ross). Three preferred algae

135 for the two sea urchins species were : $\underline{\text { P. palmata, }} \underline{\text { S. chordalis }}$ and $\underline{L}$.

136 digitata (Vachet and Guillou, pers. comm.). Because they were easier to

137 collect on a regular basis, P. palmata and L. digitata were used during the

138 long-term study. These algae were collected weekly from a site near the

139 laboratory facilities.

$141 \quad 2.2$ Feeding rates

$143 \quad 2.2 .1$ First stage 2000-2001

144 In order to select which alga (

145 preferred by the two urchins, algal ingestion rates of Paracentrotus lividus

146 and Psammechinus miliaris were recorded weekly in the laboratory from

147 March 2000 to July 2000 then from September 2000 to June 2001. Each

148 group of ten sea urchins was fed $10 \mathrm{~g}$ (WW, dried off in blotting paper) of

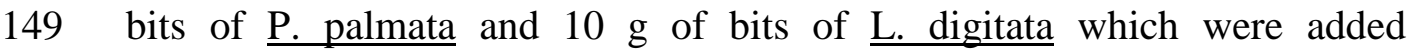


150 simultaneously in the tanks. Any food remaining after three days was

151 weighed and biomass was measured to the nearest $0.01 \mathrm{~g}$ (WW, dried off in

152 blotting paper). The ingested biomass (in $\mathrm{g}$ WW per urchin per day) was

153 calculated by subtraction. The loss of algal biomass during the time period

154 between feeding and collection has been estimated prior to the experiment

155 by weighing algae in three different tanks at different temperatures. The 156 algal loss was low, $0.4 \pm 0.7 \%$ and $1.4 \pm 1.3 \%$ at 12 and $17^{\circ} \mathrm{C}$ 157 respectively.. The $10 \mathrm{~g}$ algal ration added was always in excess of the 158 amount consumed both during and between the experiments. Tanks were 159 cleaned after each feeding session.

$161 \quad$ 2.2.2. Second stage 2001-2002

162 In the second part of the study, the ingestion rates and defaecation rates of

163 Paracentrotus lividus and Psammechinus miliaris, fed on the preferred alga

164 only, were recorded twice a month from October 2001 to August 2002.

165 Each group of ten sea urchins were fed with $15 \mathrm{~g} \mathrm{WW}$ of the preferred alga.

166 All food offered, food remaining after 3 days and faeces collected through a

167 sieve were weighed. The faeces loss during the experiment was estimated

168 according to the procedure used for algae. This loss was $2 \pm 3 \%$ and $8.8 \pm$

$1691.2 \%$ at 14 and $17^{\circ} \mathrm{C}$ respectively. For better precision, the biomasses were

170 expressed in dry weight to the nearest $1 \mathrm{mg}$. Because the offered biomass

171 was fresh and the water concentration varies seasonally in the alga, it was

172 converted to dry weight using the relationship between DW and WW

173 calculated at each feeding session. To do this, three samples of the alga were

174 first blotted dry in the paper, weighed, and then dried to constant weight 
175 (48h at $\left.60^{\circ} \mathrm{C}\right)$. The ratio of the wet weight /dry weight of these samples was

176 calculated for the conversion. Algal biomass ingested and faeces produced

177 and absorption, calculated as the difference between algal biomass ingested

178 and faeces produced, were expressed in mg DW. urchin ${ }^{-1} \cdot$ day $^{-1}$. Absorption

179 rate was the ratio between absorption and the ingested biomass multiplied 180 by 100 .

181

$182 \quad 2.3$ Environmental parameters

184 Seawater samples were collected at a station close to the seawater intake 185 that supplied the tanks in the laboratory and which was at less than 0.5 186 nautical mile from the seaweed sampling site. Samples were collected 187 weekly using the methods recommended by the French monitoring network

188 in coastal environments (SOMLIT: http://www.obs-vlfr.fr/somlit).

189 Seawater was collected two meters below the surface at high tide and when 190 the tide coefficient was $70 \pm 10$. Temperature was measured with a 191 conductivity meter ( $\mathrm{LF}$ 197). Seawater ammonium $\left(\mathrm{NH}_{4}{ }^{+}\right)$, nitrate $\left(\mathrm{NO}_{3}{ }^{-}\right)$, 192 and nitrite $\left(\mathrm{NO}_{2}^{-}\right)$were measured according to the method described in 193 Strickland and Parsons (1972), and modified for a Technicon autoanalyser 194 with an accuracy of $5 \%$. 
199 On each in situ sampling (from February 1997 to December 1998), 20

200 individuals were brought back to the laboratory and dissected. Their gonads

201 and tests were dried to constant weight $\left(48 \mathrm{~h}\right.$ at $\left.60^{\circ} \mathrm{C}\right)$. Gonad indices were

202 calculated as the ratio of the dried gonad to the eviscerated test dry weight,

203 and multiplied by 100.

204 Five times during the second stage of the experimental feeding experiment 205 (24 $^{\text {th }}$ October $2001,21^{\text {th }}$ December $2001,5^{\text {th }}$ February $2002,7^{\text {th }}$ June 2002 ,

$20619^{\text {th }}$ August 2002), five urchins of each species were isolated from the

207 additional tanks to determine the gonad index according to the previous

208 experimental protocol and to analyze the biochemical composition of the 209 gonad.

2112.5 Biochemical composition

213 The biochemical composition of the preferred alga, faeces and gonads were 214 determined at the same time as gonad indices. The contents in 215 carbohydrates, proteins and lipids of each compartment (alga, faeces and 216 gonads) were determined. Three samples of algae and three samples of

217 faeces from each urchin species were analyzed. Alga samples were rinsed 218 and epiphytes removed before the analysis. Each sample of algae and faeces 219 was divided into two parts. One part was weighed (wet weight) and then 220 dried at $60^{\circ} \mathrm{C}$ to constant weight for estimation of the water content 221 (difference between wet and dry weight). Ash content was determined on 222 the dried tissue after combustion in a muffle furnace at $500^{\circ} \mathrm{C}$ for $4 \mathrm{~h}$. The 223 second part of each sample was homogenized in distilled water using an 
224 Ultra turax and this homogenate was used for the biochemical analyses.

225 Carbohydrates were analysed using the Dubois procedure (Dubois et al., 226 1956). Nitrogen was determined by the total Kjeldahl method (TKN) 227 (protein content $=6.25 \times \mathrm{TKN})($ Indergaard and Minsaas, 1991). Total lipid 228 content was determined gravimetrically using the Bligh and Dyer method 229 (1959).

230 For the gonad analyses four sea urchins were dissected and their gonads 231 collected and homogenized with the Ultra turax. This homogenate was 232 divided in four parts: the first split was used for water content 233 determinations (drying at $60^{\circ} \mathrm{C}$ to constant weight). The dried material was 234 then combusted at $500^{\circ} \mathrm{C}$ for $4 \mathrm{~h}$ to determine the ash content of gonads. The 235 remaining 3 splits were used for measuring the levels of carbohydrates, 236 proteins and lipids using the techniques of Dubois et al. (1956), Lowry et 237 al.(1951) and Bligh and Dyer (1959), respectively.

238 The proximate organic composition of each compartment was determined 239 using the ash-free dry weight (AFDW). From these data, ingestion rates in 240 terms of organic components, (carbohydrates, proteins and lipids) were 241 expressed in mg DW.urchin ${ }^{-1}$.day ${ }^{-1}$ for each nutrient.

242 The quantity of the ingested component was equal to the percentage of this 243 component present in the alga sample at any given period multiplied by the 244 quantity of alga ingested by the sea urchin over the same time. The quantity 245 of excreted component was a function of the percentage of this material in 246 the faeces and the quantity of faeces produced by the sea urchin. The 247 quantity of component absorbed by the organism was the difference 248 between the quantity ingested and the quantities excreted. 
249 The chemical composition of the gonads was corrected by the gonad index

250 at the time of sampling in order to take into account the changes in gonad

251 weight over the length of the experiment. The index was calculated from the

252 percentage of the organic component in the gonad at a given time multiplied

253 by the gonad index at the same sampling.

$255 \quad 2.6$ Statistics

256 Changes in ingestion and defaecation rates, gonad index, quantities of

257 ingested components (carbohydrates, proteins, lipids), of absorbed

258 components and chemical composition of the gonad, were tested for each

259 sea urchin species with a one-way analysis of variance (ANOVA) $(P<$

260 0.05) with the least significant difference test once the homogeneity of

261 variance had been tested. The gonad index of experimental and control

262 animals were arcsine-transformed.

263 All analyses were done with the statistical software STATGRAPHICS 4.

2663 Results

\section{3.1 Environmental variations}

270 Ammonium $\left(\mathrm{NH}_{4}^{+}\right)$, nitrate $\left(\mathrm{NO}_{3}{ }^{-}\right)$, and nitrite $\left(\mathrm{NO}_{2}^{-}\right)$levels increased 271 beginning in October 2001 (Fig.1a). The main peak of ammonium was 272 observed at the end of October $(2.4 \mu \mathrm{M})$ followed by a nitrite peak at the 273 end of November $(0.75 \mu \mathrm{M})$ and a nitrate concentration peak in mid- 
274 February $2002(23.6 \mu \mathrm{M})$. Then nitrates decreased in March when

275 chlorophyll $a$ showed a small peak (Fig. 1a and b). Nitrites and nitrates

276 dropped to very low levels in March and May respectively, and stayed low

277 until September during the temperature maximum (Fig. 1a).

278 Ammonium reached its lowest levels from March to the end of June

279 followed by a new peak at the beginning of August. Successive peaks of

280 chlorophyll $a$ occurred from mid-May to the end of August (Fig. 1b).

$282 \quad 3.2$ Reproductive cycle

284 Field data obtained in 1997 and 1998 on the Paracentrotus lividus 285 reproductive cycle in the Bay of Brest indicated that the time when 286 spawning started, marked by a drop in the GI, differed between years (Fig.

287 2a). In 1997, the GI reached a maximum in May (GI=7) and then decreased 288 sharply, indicating a short spawning period. In contrast during 1998, the GI 289 decrease was small during winter and spring. Each year, the minimum GI 290 values were observed in June and followed by a rapid increase. Spawning of 291 Psammechinus miliaris occurred from early March to mid-June in 1997 and 292 from mid-April to mid-June in 1998 (Fig. 2b). The GI reached maximum 293 values of 12 and 8 respectively, and a minimum value of 2 . This low level 294 reflecting the resting stage remained steady during about 3 months.

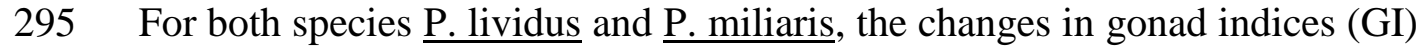
296 under experimental conditions confirmed the seasonal variations (Fig. 2a 297 and b). For P. lividus, the GI increased from October $2001(\mathrm{GI}=2)$ to June 2982002 (GI=8). In August, the GI value was still high. Comparison with the 
299 field data suggested the spawning event in the experimental study would be

300 around the maximum GI value (8) observed in June. After the onset of

301 spawning, which cannot be precisely defined here, the GI might drop to a

302 low level located in mid-June in both sets of field data (1997 and 1998).

303 Spawning marks were observed visually in the laboratory tanks during this

304 time. Thus, the GI estimated in August would be during the recovery stage

305 of the gonad, as the post-spawning stage, or resting stage, was very short in

306 the field confirming the previous studies on P. lividus (Byrne, 1990; Spirlet

307 et al., 1998). For $\underline{\text { P. miliaris, }}$, GI values increased significantly from

308 December 2001 (GI=5) and reached the highest value (15) in February

309 2002, after which the GI value decreased and reached a minimum level in

310 August 2002 (GI=2.6). The high level observed in February compared to the

311 field data situated the onset of spawning event close to February. As for $\underline{\mathrm{P}}$.

312 lividus the two sets of 1997 and 1998 field data indicated that the end of

313 spawning took place in June. The very low value measured in August 2002,

314 and similar to the field observations, suggests the gonads were in resting

315 stage. The field and experimental observations indicate that spawning

316 occurred earlier in $\underline{\text { P. miliaris }}$ than in $\underline{P \text {. lividus }}$.

$318 \quad 3.3$ Feeding preference

320 The feeding rates on Palmaria palmata and Laminaria digitata for the two 321 urchin species Paracentrotus lividus and Psammechinus miliaris from March 3222000 to June 2001 are presented in the figure 3 using units of $\mathrm{g} \mathrm{WW}$. urchin $323{ }^{1}$.day $^{-1}$. With respect to $\underline{\text { P. lividus }}$ (Fig. 3a) three feeding rate trends were 
324 observed: from March 2000 to July 2000 (except for April 2000), sea

325 urchins ingested quantities significantly larger of $\underline{L}$. digitata than $\underline{P}$. palmata,

326 then from September 2000 to June 2001, the ingestion of $\underline{L}$. digitata and $\underline{P}$.

327 palmata did not differ significantly, and finally, from May 2001 to June

328 2001, the ingested biomass of $\underline{P}$. palmata were higher than those of $\underline{L}$.

329 digitata ones $(P<0.05)$.

330 For P. miliaris, (Fig.3b), two stages could be distinguished: from March

3312000 to September 2000 , the feeding rates on $\underline{L}$. digitata and P. palmata

332 were not significantly different, and in the second stage, from October to

333 June 2001 , more $\underline{P \text {. palmata }}$ was ingested than $\underline{\mathrm{L} \text {. digitata }}(P<0.05)$. The

334 ingestion rate of $\underline{P}$. palmata increased significantly during this last period.

335 This increase coincided with a decreasing consumption of $\underline{L}$. digitata over

336 the same period.

337 Finally the both species presented a similar pattern with a higher attraction

338 for P. palmata with time.

$340 \quad 3.4$ Ingested and defaecated biomasses during 2001-2002

342 Based on the previous results, Palmaria palmata was used for the second

343 part of the study. Samples were collected in Dellec Cove, near the seawater

344 sampling station. In both species, changes in ingestion and defaecation rates

345 had a similar pattern, with more pronounced variations in Psammechinus

346 miliaris than in Paracentrotus lividus (Fig. 4a and b). A decrease in

347 ingestion rate was observed from February (60 mg DW urchin $\left.{ }^{-1} \mathrm{~d}^{-1}\right)$ to April

348 (30 mg DW urchin $\left.{ }^{-1} \mathrm{~d}^{-1}\right)$ in $\underline{\text { P. lividus, }}$, and from January (79 mg DW urchin 
$\left.349{ }^{1} \mathrm{~d}^{-1}\right)$ to April (20.5 mg DW urchin $\left.{ }^{-1} \mathrm{~d}^{-1}\right)$ in P. miliaris. After April, ingestion

350 rates increased through June (50 and $68 \mathrm{mg} \mathrm{DW}$ urchin $^{-1} \mathrm{~d}^{-1}$ for $\underline{P \text {. lividus }}$

351 and $\underline{P}$. miliaris respectively) and remained high through summer.

352 The pattern of defaecation followed that of ingestion with mimima observed

353 in April. Changes were significantly more pronounced for $\underline{\text { P. miliaris }}$ than

354 for P. lividus.

355

3563.5 Biochemical composition of Palmaria palmata

358 Biochemical analyses done on Palmaria palmata five times during the year

359 showed seasonal changes in organic component levels (Fig. 5).

360 Carbohydrates increased significantly from October (40.4\% AFDW) to

361 December $(53.2 \%)$ then remained constant until August $(P<0.05)$.

362 Proteins increased significantly from December (12.4\%) to February (24.4

$363 \%)$ and then decreased from June to August (13.7\%). The maximum level

364 of proteins in P. palmata was measured in February and June.

365 Lipids increased significantly from February $(0.4 \%)$ to June $(1.1 \%)$ and 366 reached their maximum value in August (1.3\%).

3683.6 Quantity of ingested nutrients

370 The estimated ingestion of carbohydrates remained constant for 371 Paracentrotus lividus throughout the annual cycle, about $20 \mathrm{mg}$ DW. urchin

$372{ }^{1} \cdot \operatorname{day}^{-1}(\mathrm{P}>0.05)$ (Fig. 6a). For Psammechinus miliaris, the quantity of 373 ingested carbohydrates increased significantly from October (19.6 mg DW. 
$374 \operatorname{urchin}^{-1} \cdot$ day $\left.^{-1}\right)$ to December $\left(26.8 \mathrm{mg} \mathrm{DW}\right.$. urchin ${ }^{-1} \cdot$ day $\left.^{-1}\right)$ and reached its

375 maximum level in February and June (29.5 mg DW. urchin $^{-1}$.day ${ }^{-1}$ ) (Fig.

376 6b). Then it decreased from June to August (26.1 mg DW. urchin $^{-1}$.day ${ }^{-1}$ ).

377 The estimated quantity of proteins ingested by $\underline{P \text {. lividus }}$ and $\underline{P \text {. miliaris, }}$,

378 increased significantly from October $\left(6.3 \mathrm{mg}\right.$ and $6 \mathrm{mg}$ DW. urchin ${ }^{-1} \cdot \mathrm{day}^{-1}$,

379 respectively) to February $\left(9.6 \mathrm{mg}\right.$ and $14.3 \mathrm{mg} \mathrm{DW}$. urchin ${ }^{-1} \cdot \mathrm{day}^{-1}$,

380 respectively). However, in $\underline{P \text {. lividus the maximum level occurred in June }}$

381 (12.1 mg DW. urchin $\left.{ }^{-1} \cdot \mathrm{day}^{-1}\right)(P<0.05)$, while in $\underline{\mathrm{P} . \text { miliaris }}$ it was

382 observed in both February (14.3 mg DW. urchin ${ }^{-1}$.day $\left.{ }^{-1}\right)$ and June samples

383 (15.7 mg DW. urchin ${ }^{-1}$ day $^{-1}$ ) which were not significantly different. In both

384 species the quantity of proteins ingested decreased significantly between

385 June and August.

386 With respect to the lipids, the estimated quantity ingested by each species

387 increased significantly between February (0.17 and $0.18 \mathrm{mg} \mathrm{DW}$. urchin $388{ }^{1}$.day $^{-1}$, respectively) and June (0.53 and $0.68 \mathrm{mg}$ DW. urchin ${ }^{-1}$.day ${ }^{-1}$, 389 respectively). Maximum levels of lipids were ingested in June and August.

3913.7 Total absorption rate and quantity of absorbed components

393 The total absorption rate was high for both species (Fig. 4). In

394 Psammechinus miliaris a period of low absorption occurred in May $(60.1 \pm$ $3956.36 \%$ ) between two periods of high, but significantly different, absorption 396 rates, the first from October to the end of April $(82.1 \pm 5.5 \%)$ and the 397 second from the mid-June to the end of August $(77.6 \pm 4.9 \%)$. In 398 Paracentrotus lividus the absorption rate was homogeneous over the year 
$399(87.6 \pm 3 \%)$ and was significantly higher than even the high absorption rate

400 periods of $\underline{\mathrm{P} \text {. miliaris }}(\mathrm{P}<0.05)$. With respect to the different components,

401 the absorption of carbohydrates was significantly higher in P. miliaris than

402 in $\underline{P}$. lividus $(97 \pm 1 \%$ versus $86 \pm 7 \%$ in). The protein absorption did not

403 vary significantly between the two species $(78 \pm 9 \%$ and $80.5 \pm 7 \%$ for $\underline{P}$.

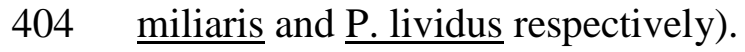

405 The amount of an absorbed biochemical component was considered relative

406 to the ingested and defaecated biomass of the same component (Fig. 7). The

407 quantity of absorbed carbohydrates was not significantly different during the

408 annual cycle for each species but was significantly different $(P<0.05)$

409 between both species with $20.7 \pm 1$ and $26.4 \pm 4 \mathrm{mg} \mathrm{DW} \cdot \operatorname{urchin}^{-1}$.day ${ }^{-1}$ for $\underline{P}$.

$410 \underline{\text { lividus }}$ and $\underline{\text { P. miliaris }}$ respectively. Both species exhibited similar changes

411 in the absorption of proteins. The quantity of absorbed proteins increased

412 significantly from October (4.9 and $4.8 \mathrm{mg} \mathrm{DW.urchin}{ }^{-1}$.day ${ }^{-1}$ for $\underline{\text { P. lividus }}$

413 and $\underline{P \text {. miliaris }}$ respectively) to February (7.12 and $9.9 \mathrm{mg}$ DW.urchin ${ }^{-1}$.day

414 1) and then from February to June (11.2 and $13.8 \mathrm{mg} \mathrm{DW} \cdot \mathrm{urchin}^{-1}$.day ${ }^{-1}$ ).

415 This increase was followed by a decrease from June to August (4.3 and 5.7

$416 \mathrm{mg})(P<0.05)$.

417 For both $\underline{\mathrm{P} \text {. lividus }}$ and $\underline{\mathrm{P} \text {. miliaris, }}$, the absorption of lipids was only

418 quantifiable in June and August (0.37 and $0.46 \mathrm{mg} \mathrm{DW.urchin}{ }^{-1}$.day ${ }^{-1}$ in $\underline{P}$.

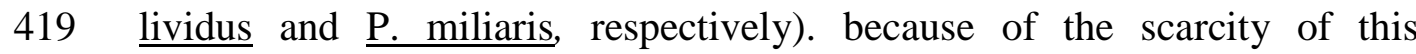

420 component in the alga.

421

4223.8 Biochemical composition of the gonad

423 
424 The quantity of carbohydrates in the gonad increased significantly for both

425 species, from December to February and then decreased from February to

426 June $(P<0.05)$ (Fig. 8).

427 The protein content in Paracentrotus lividus gonads increased steadily and 428 significantly from October and reached its maximum level in June $(P<$

429 0.05); it decreased between June and August, but remained superior to

430 October and December values. For Psammechinus miliaris, the quantity of

431 proteins in the gonads increased significantly from December to February

432 then decreased steadily and significantly to August. The level in August was

433 lower than that in October $(P<0.05)$.

434 The quantity of lipids in gonad samples increased significantly for $\underline{\text { P. lividus }}$

435 from December to February, decreasing thereafter into August. For $\underline{P}$. 436 miliaris, an important significant increase was observed between December

437 and February, followed by successive significant decreases in both June and 438 August $(P<0.05)$.

\section{4. Discussion}

$443 \quad 4.1$ Palmaria palmata as a nutritional source

445 One of our first objectives was to determine the preferred alga by the 446 two sea urchin species in order to use a monospecific, natural diet for 447 subsequent experiments. A previous study (Vachet, unpublished) suggested 448 the sea urchins had a preference for two algae already used commonly in 
449 echiniculture: Palmaria palmata and Laminaria sp. (Basuyaux and Blin,

450 1998; Kelly, 2001, Spirlet et al., 2000). In the present study, sea urchins

451 were fed $\underline{\text { P. palmata }}$ and L. digitata for more than one year. Analysis of the

452 results showed that, in the short term (6 months), there was a variable

453 consumption rate of the two algae, by the sea urchin species. Over longer

454 time periods, there was a progressively greater consumption of $\underline{\mathrm{P} . \text { palmata }}$

455 by both urchin species. In this first experiment, this change in feeding

456 preference was not directly correlated to changes in alga composition or in

457 sea-urchin maturity as the feeding response during the period of intense

458 modifications in algae and in sea-urchin gonads (April-June) was

459 significantly different between 2000 and 2001. Lemire and Himmelman

460 (1996) have classified different algae according to their ability to support

461 somatic and gonadic growth (using hierarchal cluster analysis), and reported

462 that both these algae contributed strongly to the fitness of another urchin

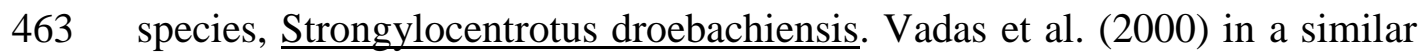

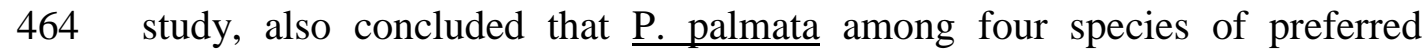

465 macroalgae "induced the quickest and highest" enhancement in gonad index

466 values. The improvement in gonad yield has been credited to the high

467 protein levels measured in this alga (Fleurence, 1999 and Martinez and

468 Rico, 2002), an explanation discussed by other investigators (see review

469 Morgan et al., 1980 and Hagen Rødde et al. 2004). L. digitata contains a low

470 proportion of protein and a relatively high proportion of complex

471 carbohydrates (Otero-Villanueva et al., 2004) that can explain the poorer sea

472 urchin ingestion, absorption and assimilation efficiencies. 
473 Our study showed an increase in total protein in the alga, $\underline{P \text {. palmata }}$

474 between October and December, and maximum values were reached in

475 February and June (24.4\% AFDW). These values were close to the

476 maximal values reported from other studies in Brittany (about 25\% from

477 March to May in the southern part (Galland-Irmouli et al., 1999) and 22 to

$47820.4 \%$ between February and April in the northern part (Rouxel et al.,

479 2001)) and were superior to values reported from the northern Spanish alga

480 populations (18\% between March and May (Martinez and Rico, 2002)).

481 The main difference between all these populations was the maintenance of a

482 high protein level during June in P. palmata from the Bay of Brest, while the

483 protein level decreased to $10 \%$ in other populations along the coast of

484 Brittany and declined to $2 \%$ at the Spanish sites. The maintenance of a high

485 protein content in $\underline{P}$. palmata was probably related to the seawater nitrate

486 concentration. Nitrate is the most available $\mathrm{N}$ source and is the main

487 inorganic nutrient involved in algal nutrition (Chapman and Craige, 1977).

488 A rapid increase in protein contents of $\underline{P \text {. palmata follows high }}$

489 concentrations of seawater nitrate (Morgan and Simpson, 1981). In our

490 study, the increase was concomitant with the increase in seawater $\mathrm{NO}_{3}{ }^{-}$and

$491 \mathrm{NO}_{2}^{-}$concentrations and the maximum protein content occurred during the

492 peak of $\mathrm{NO}_{3}{ }^{-}$. The overall seawater nitrogen concentrations in the Bay of

493 Brest (maximum $\mathrm{NO}_{3}^{-}+\mathrm{NO}_{2}^{-}{ }^{-} 24 \mu \mathrm{M}$ ) was higher compared to those on the

494 Spanish coast $(9 \mu \mathrm{M})$.

$495 \quad$ P. palmata in our study remained very rich in proteins even in June.

496 These proteins serve as a reserve source used for growth, maintenance and

497 reproduction by the alga. In Brittany, the reproductive stage of $\underline{P}$. palmata 
498 occurs during winter and the maximum growth rate, during winter and

499 spring (Le Gall, 2002). Thus in June the protein content should have been

500 low in the alga as it is the case in the Spanish coast, except if a nitrogen

501 source was still present in the seawater., Two indices suggests the higher

502 level of nitrogen in the Bay of Brest; the first is the presence of low but not

503 insignificant concentrations of $\mathrm{NH}_{4}{ }^{+}$which can also be utilized by the algae

504 to contribute to the maintenance of growth (Martinez and Rico, 2002). The

505 second is the occurrence of successive peaks of chlorophyll $a$,

506 corresponding to phytoplankton blooms, from May to the end of August.

507 These summer peaks of low intensity typical of the Bay of Brest ecosystem

508 (http://www.obs-vlfr.fr/somlit) suggest sufficient nutrients were present to

509 support bloom conditions, which could benefit the macroalgae also.

$511 \quad 4.2$ Changes in ingestion and defaecation rates

513 In the two sea urchin species, monthly variations were observed for

514 both ingestion and defaecation rates. The possible loss in alga and faeces

515 biomass during the experiment was too low to explain the main changes.

516 The difference in timing for the start of an ingestion rate decrease (in

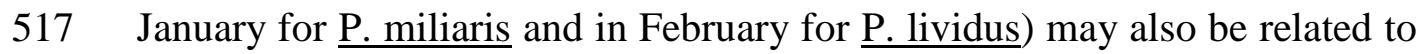

518 the relative stage of maturity in each species. During 2002, the highest GI

519 reported here, and corroborated by the earlier field data (Fig. 2), showed that

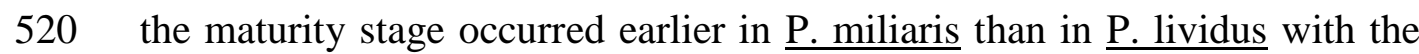

521 bay of Brest environmental conditions. Some previous studies have shown

522 that echinoid feeding rates decrease before spawning (Fuji, 1967, De Ridder 
523 and Lawrence, 1982). The reason for this phenomenon may be

524 physiological or due to the gonad size increase into the coelomic space

525 during the gametogenesis. The first hypothesis is plausible for both species,

526 but the second only concerns $\underline{P \text {. miliaris, }}$, since the $\underline{\text { P. lividus }}$ GI was high in

527 April when feeding activity increased again. In both species, the increase in

528 food consumption was concomitant with a water temperature increase in

529 mid-April, suggesting temperature can control the sea urchin feeding rates

530 also (see review Lares and Mc Clintock, 1991).

531 The defaecation rate changes in both species mimicked, in general, changes

532 in ingestion rates. The total nutrient absorption rates were high (mean

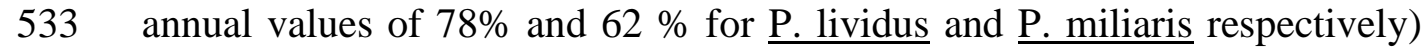

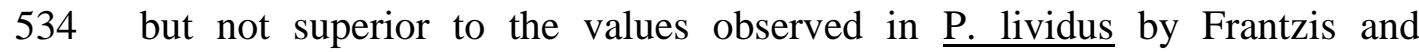

535 Grémare (1992), often above $80 \%$. P. miliaris presented absorption rates

536 significantly lower and seasonal changes in ingestion and defaecation rates

537 more pronounced than $\underline{P \text {. lividus }}$ For $\underline{\text { P. miliaris, }}$, total nutrient absorption

538 was significantly lower after the spawning event, than between October and

539 April during the gametogenesis stage. This process is probably related to

540 progressive increase of reserve storage for gametogenesis.

5424.3 Changes in nutrient absorption rate: connection with the proximate

543 composition of food and gonad

545 Absolute changes in absorption rate differed for each nutrient, but the 546 patterns were very similar for both species. The carbohydrates were

547 absorbed uniformly throughout the year, in contrast to the absorption of 
548 proteins and lipids, which changed seasonally. The absorption of proteins

549 significantly increased from October to June, and then decreased from June

550 to August when the absorption of lipids increased. These changes in sea

551 urchin nutrient absorption were linked to several factors: the total

552 concentration of the nutrient in the food, the specific composition of lipids,

553 carbohydrates and proteins, the physiological requirements of the sea urchin

554 for a particular nutrient, and the digestive characteristics of the sea urchin,

555 (especially its enzymatic equipment). Without data on changes in specific

556 composition of the nutrients and their digestibility in the sea urchins, this

557 discussion was only based on the relationship between the proximate

558 organic composition of the alga and its absorption by the sea urchins with a

559 particular attention to the gonad production.

560 For the two sea urchin species in our study, carbohydrate absorption was not

561 affected by diet as has been previously described in Watts et al., (1998) for

562 Lytechinus variegatus (L). In our study, the carbohydrate absorption did not

563 vary during the year-long experiment, even though this component

564 increased significantly in Palmaria palmata from October to December. The

565 carbohydrate absorption rate strongly suggest that these sea urchins were

566 efficient in digesting the available carbohydrates. However, overall lower

567 carbohydrate absorption recorded for $P$. miliaris suggest that P.lividus has

568 better enzymatic conditions for digesting the insoluble carbohydrate fraction

569 (which can represent about 55\% of the dry weight of P. palmata) (Lahaye,

570 1991; Hagen Rødde et al., 2004). Total carbohydrate absorption was

571 probably not affected by physiological demand for reproduction because the

572 maximum need in this component (essentially as glycogen, Monteiro- 
573 Torreiro and Garcia-Martinez, 2003) would have been between February

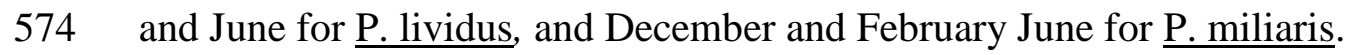

575 Lipid absorption was only observed in June and August when their levels

576 were maximal in P. palmata. With a total lipid content of more than $1 \%$ in

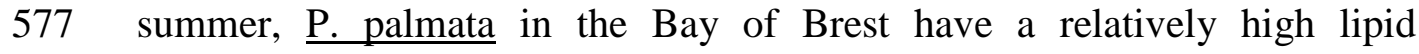

578 concentration (Sanchez-Machado et al., 2004). There was no significant

579 difference in the mean quantity of lipids absorbed by the two sea urchins

580 during this period. Their absorption reflects the significant increase of lipids

581 in the food source and could not be linked to reproductive needs: the

582 maximum gonad demand for this nutrient was in February for both sea

583 urchin species.

584 The protein level in P. palmata increased from October to February. This

585 increase was followed by the increase of ingested proteins from October to

586 February for $\underline{P \text {. miliaris }}$ and from October to June for $\underline{P \text {. lividus. In both }}$

587 species, the maximum level of absorbed protein was observed in June. From

588 February, the quantity of absorbed protein was significantly higher in $\underline{P}$.

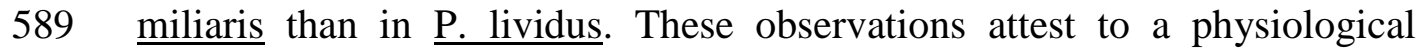

590 relationship between the increase in the protein absorption and reproduction,

591 the gonad growth phase being earlier in $\underline{P \text {. miliaris }}$ than in $\underline{P}$. lividus. Protein

592 is the major component of $\underline{\mathrm{P} \text {. lividus }}$ and $\underline{\mathrm{P} . \text { miliaris }}$ gonads (Monteiro-

593 Torreiro and Garcia-Martinez, 2003) and the need for this nutrient increases

594 strongly before spawning (Fenaux et al., 1977; Fernandez, 1998, Monteiro-

595 Torreiro and Garcia-Martinez, 2003). In our study, this requirement was

596 highest in February for $\underline{P . \text { miliaris }}$ and in June for $\underline{P \text {. lividus }}$ and would have

597 been supported by the high protein content in $\underline{P}$. palmata production during 
598 the same period. The protein conversion from ingested food to gonad

599 biomass is known to be rapid (Fernandez, 1996) and suggests that gonadal

600 growth cannot be effective when only protein reserves are available. The

601 organism needs the protein-rich food also.

602 The relationship between gonad yield and protein content in algae (Lowe

603 and Lawrence, 1976; Larson et al., 1980; Vadas et al., 2000) or in prepared

604 feeds (see review Pearce et al., 2003) is well-documented. Comparing the

605 GI obtained experimentally with the monospecific $\underline{\text { P. palmata diet and the }}$

606 GI observed in the field suggested that this protein-rich alga enhances the

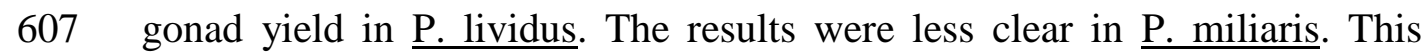

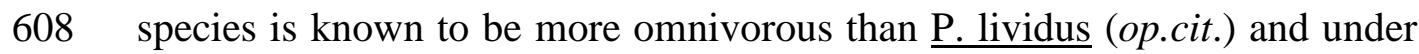

609 natural conditions, $\underline{\text { P. miliaris }}$ feeds on algae and large numbers of

610 encrusting intertidal organisms such as mussels or barnacles (Kelly and

611 Cook, 2001), increasing its protein input.

612 Our experimental results showing the stronger preference of $\underline{P . \text { miliaris }}$ for

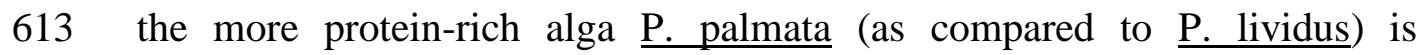

614 consistent with the possibility that $\underline{\text { P. miliaris }}$ has a higher protein

615 requirement. Higher protein ingestion may also explain the higher in situ $\underline{P}$.

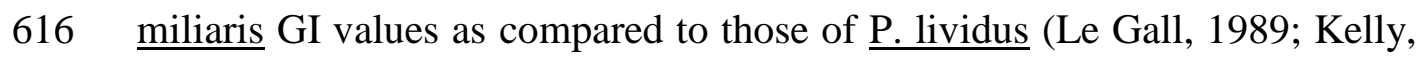

617 2000; this study). The enhanced gonad index in $\underline{P \text {. lividus }}$ when fed a

618 monospecific high protein diet suggests that the optimum protein level

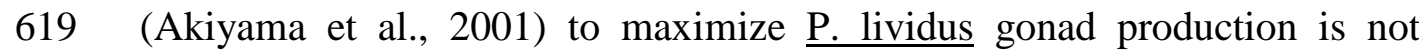
620 reached under natural conditions, compared to $\underline{\text { P. miliaris. A protein-rich }}$

621 algal diet, atypical for $\underline{\text { P. lividus, }}$ could favour gonad growth in this species,

622 whereas $\underline{\text { P. miliaris }}$ can utilise food of animal origin under natural 
623 conditions. The quantity of ingested and absorbed nutriments per urchin per

624 day related to the sea urchin test biomass was higher in $\underline{P}$. miliaris than in $\underline{P}$.

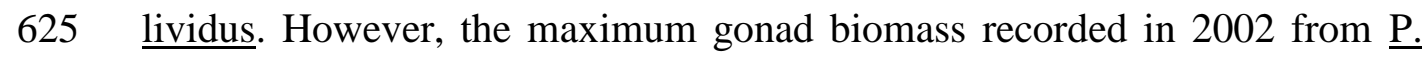

626 miliaris $(0.45 \mathrm{~g}$ DWW) remained low compared to the maximum gonad

627 biomass from $\underline{\text { P. lividus }}(0.70 \mathrm{~g}$ DWW). In the same way, the conversion

628 efficiency of food to gonadal production at a mature stage (ratio of ingestion

629 rate to gonad growth rate) is better for P. lividus than for P. miliaris (20\%

630 and $9 \%$ respectively). Under echiniculture conditions, gonad production

631 enhancement by protein input from natural food sources is likely to be more

632 productive for $\underline{\mathrm{P} \text {. lividus }}$ than $\underline{\mathrm{P} \text {. miliaris. }}$.

633

634 


\section{LEGENDS}
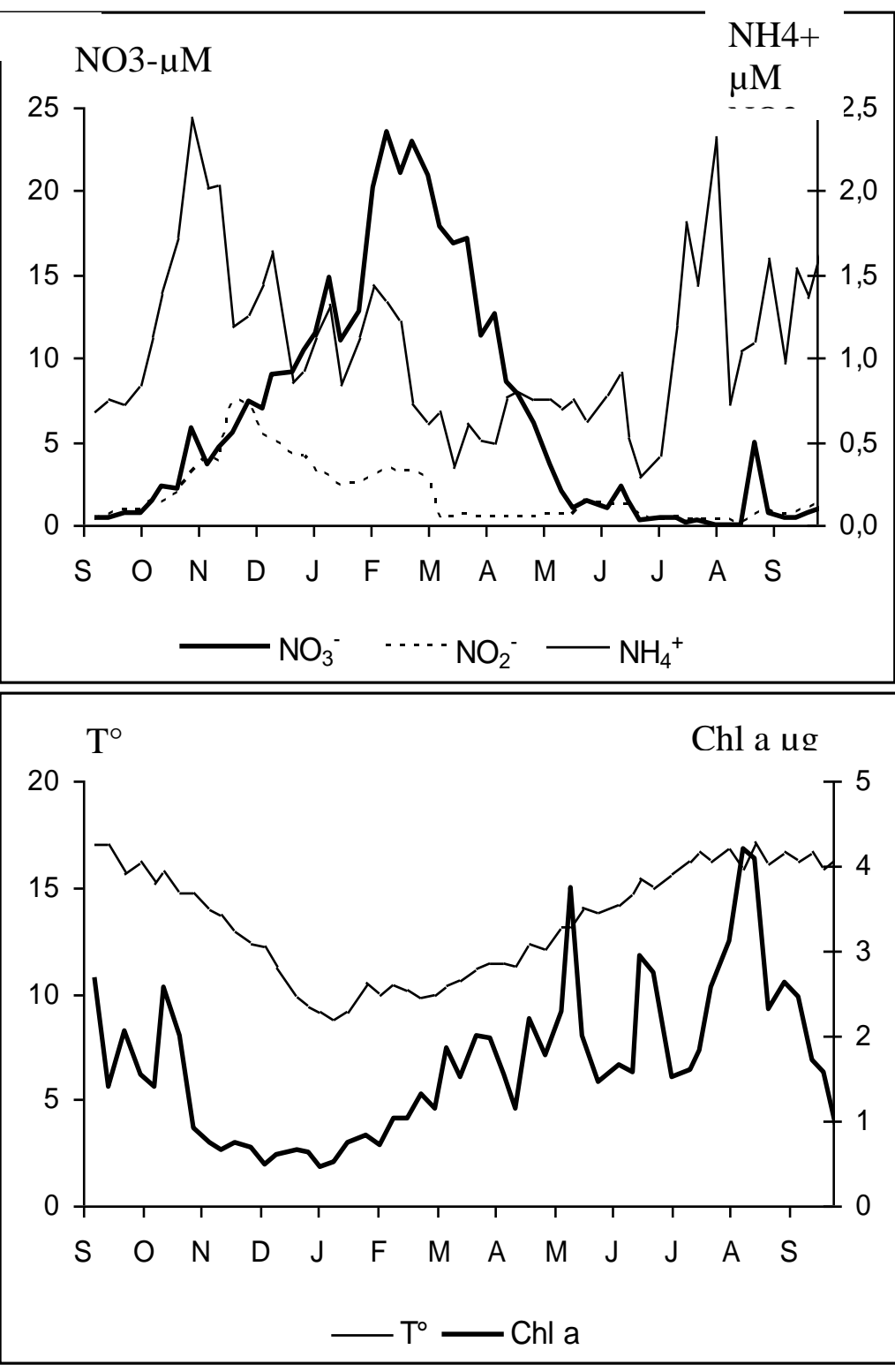

637 Fig.1.Seasonal changes in the seawater parameters in the Bay of Brest. from

638 September 2001 to October 2002 : a : ammonium, nitrite and nitrate; b : 639 temperature and chlorophyll $a$ 

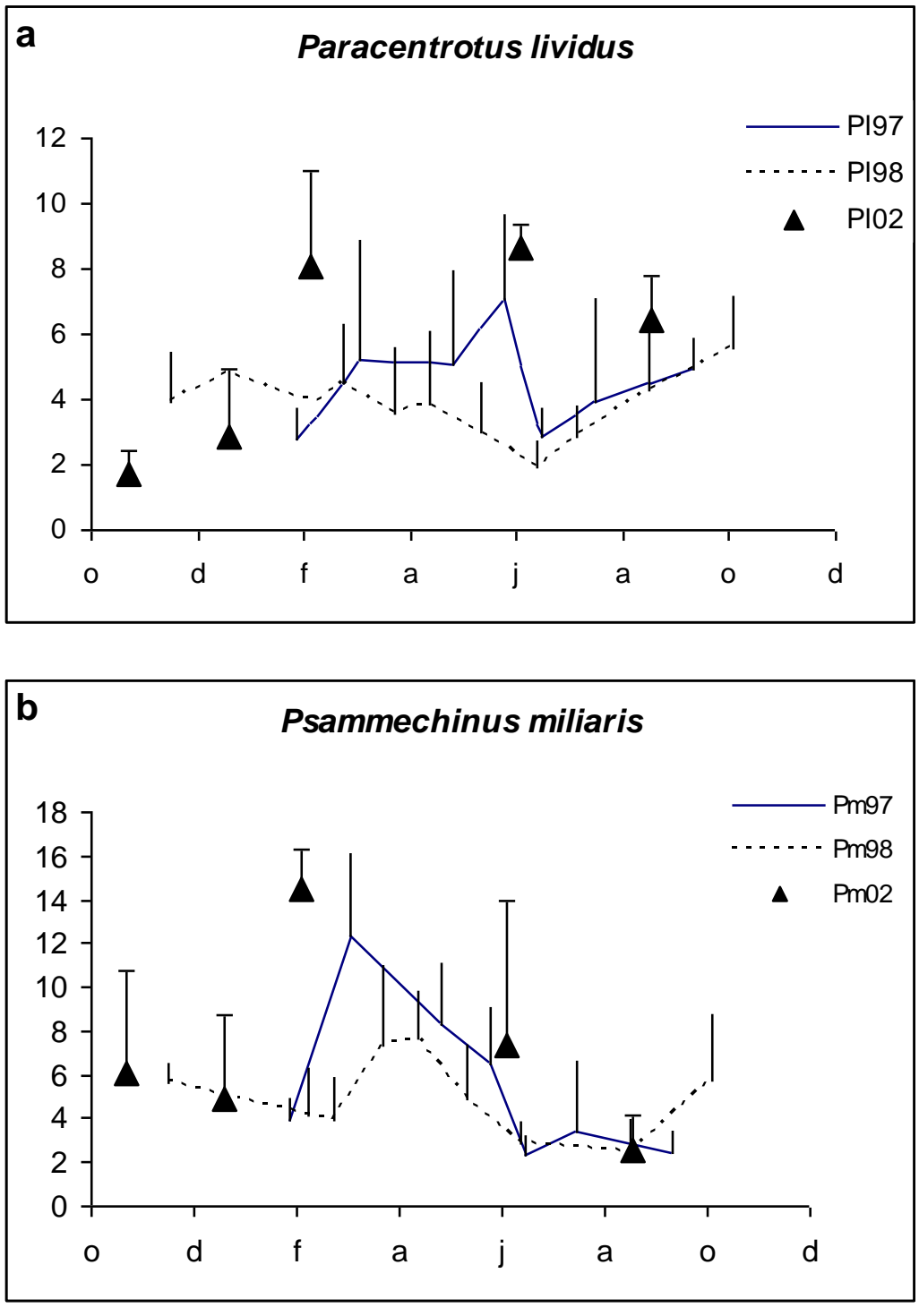

641 Fig. 2 Gonad indices (in \% of dry weight) during the experiment (black

642 triangle $+\mathrm{SD}$ ) compared to the IG seasonal changes recorded in 1997 and 6431998 from in situ populations

644 

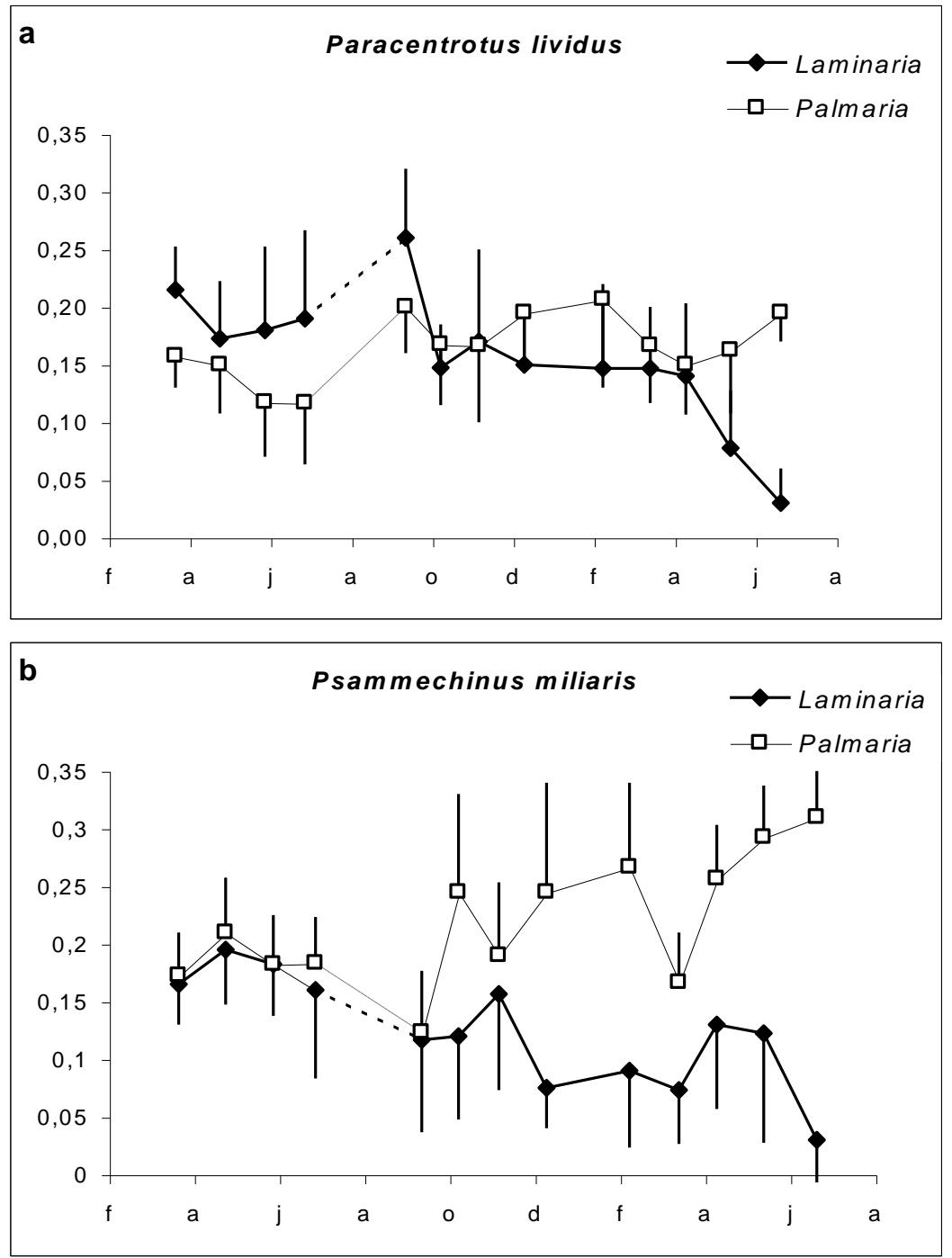

645

646 Fig. 3 Seasonal changes in the biomass of Laminaria digitata and Palmaria

647 palmata ingested by the sea urchins (in $\left.\mathrm{g} \mathrm{WW} \mathrm{d}^{-1} \operatorname{urchin}^{-1}\right)( \pm \mathrm{SD})$ from

648 March 2000 to March 2001; a : Paracentrotus lividus; b : Psammechinus 649 miliaris.

650 


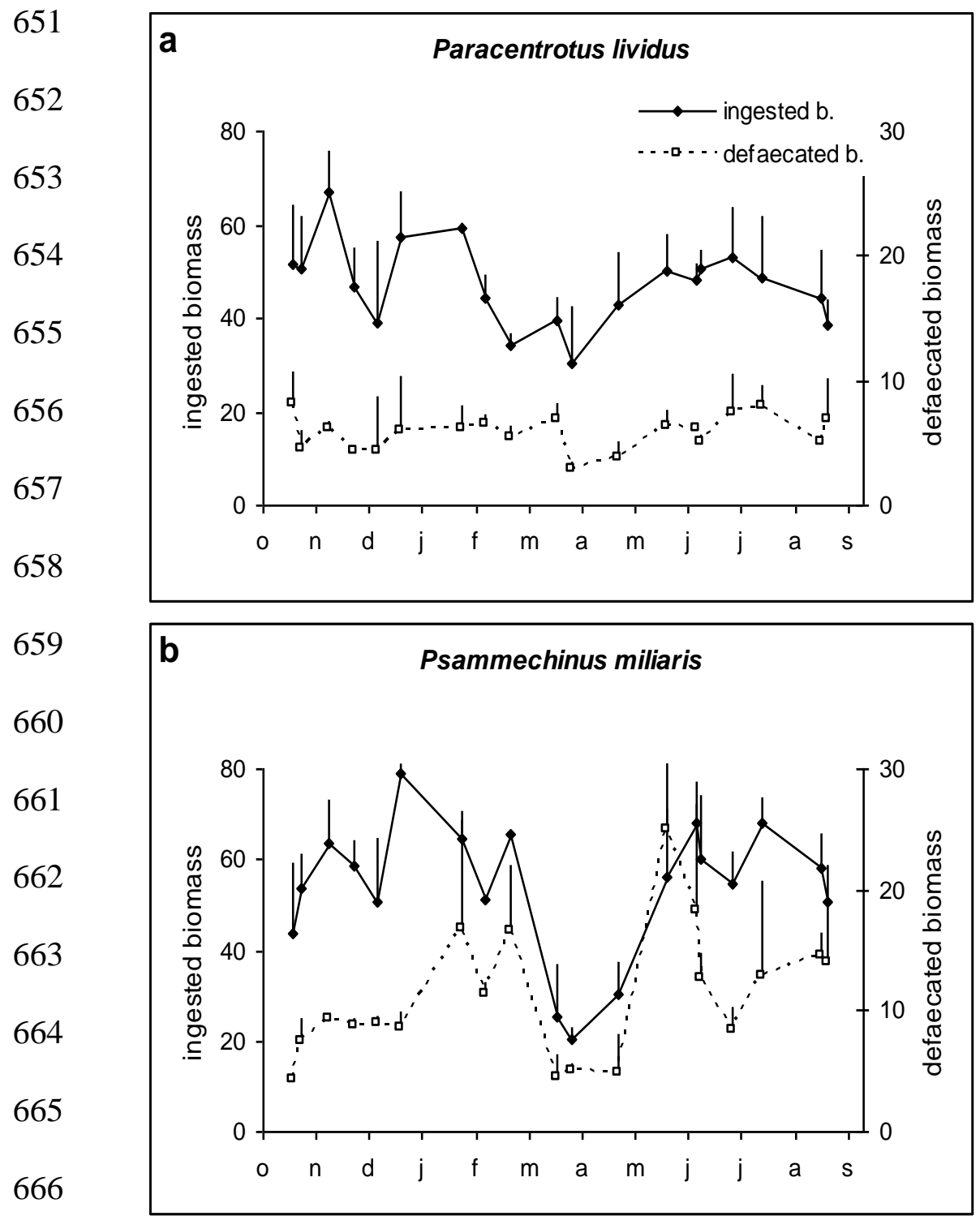

667 Fig. 4 Seasonal changes in the ingestion and defaecation rate of the sea

668 urchins fed Palmaria palmata (in mg DW d ${ }^{-1}$ urchin $\left.^{-1}\right)(+\mathrm{SD})$ from October

6692001 to August 2002. a : Paracentrotus lividus; $b$ : Psammechinus miliaris.

670 


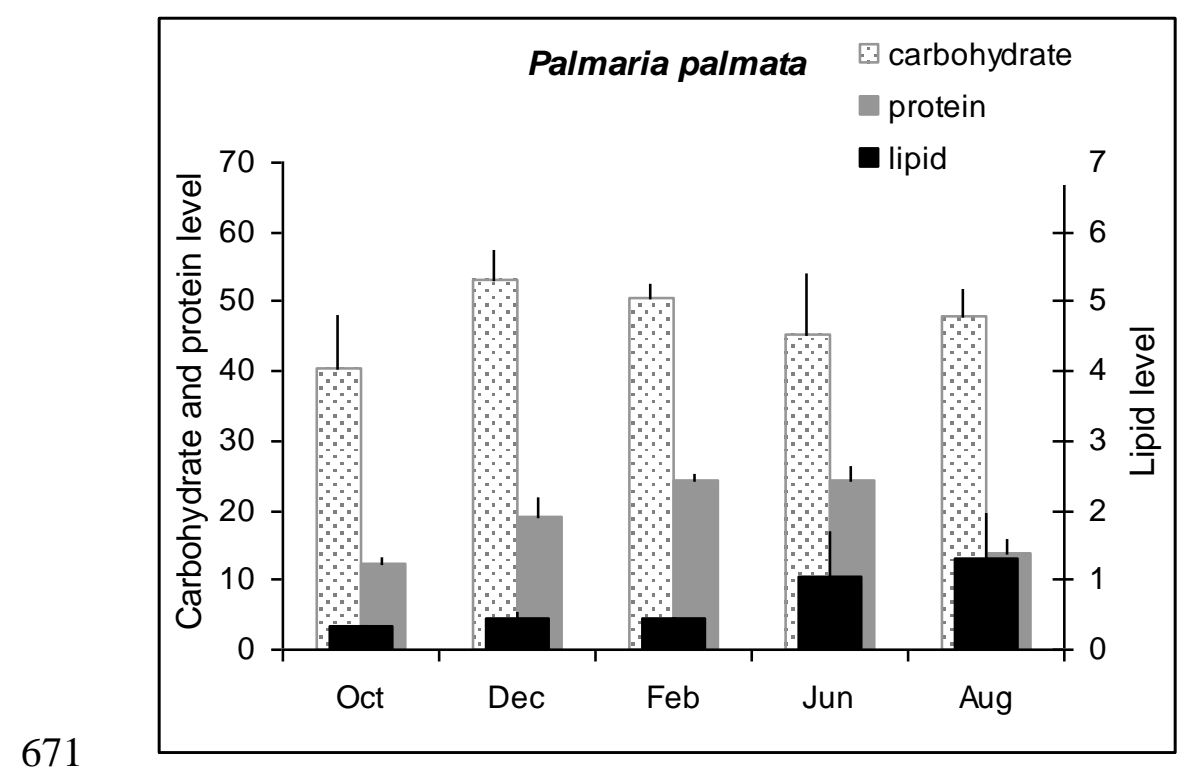

672 Fig. 5 Seasonal changes in the proximate organic composition of Palmaria

673 palmata (in \% of DW) (+SD)

674 

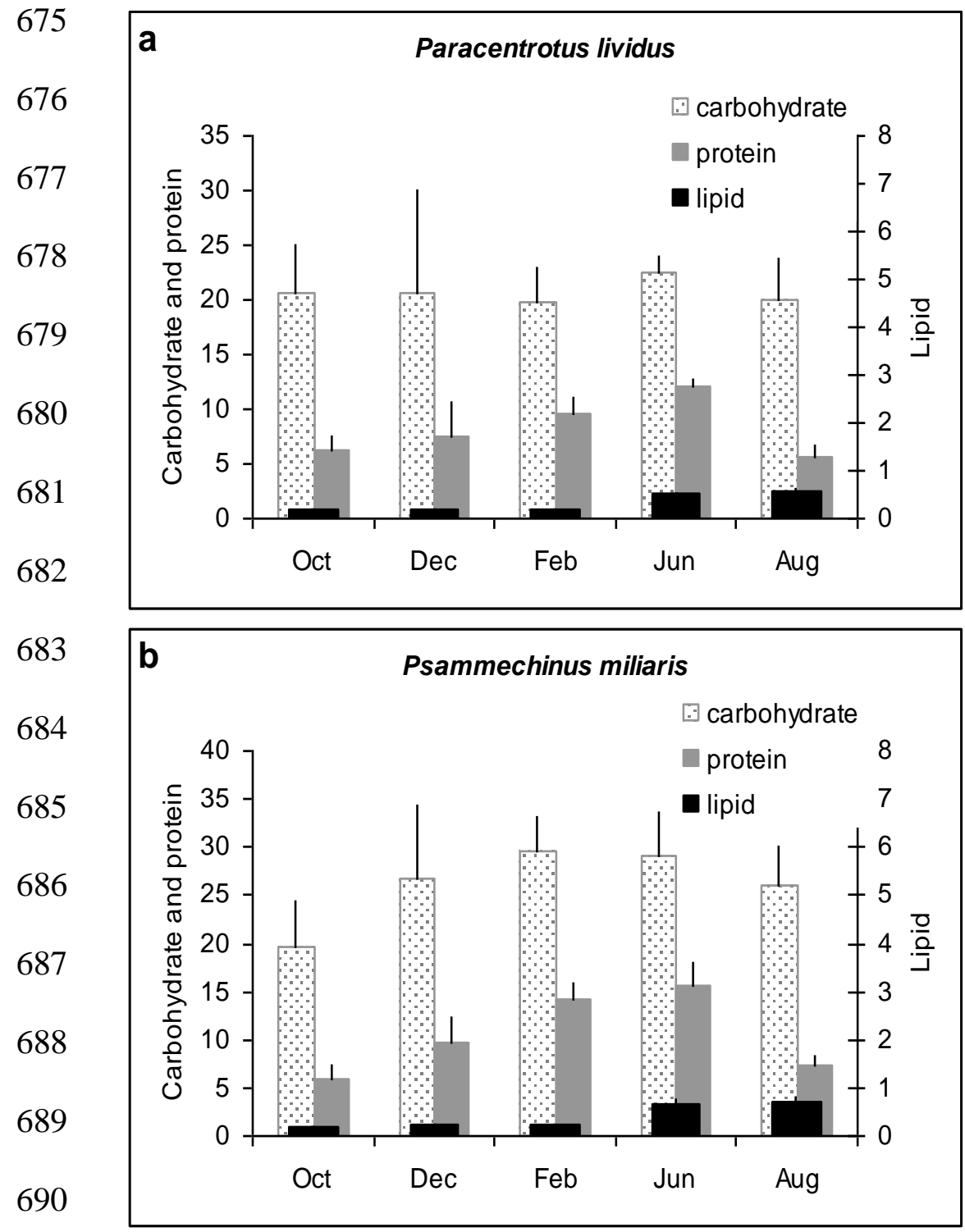

691

692 Fig. 6 Seasonal changes in the ingestion rate of the sea urchins fed Palmaria

693 palmata in term of proteins, carbohydrates and lipids (in mg DW d ${ }^{-1}$ urchin $^{-}$)

694 (+SD). a : $\underline{\text { Paracentrotus lividus; }}$ b : $\underline{\text { Psammechinus miliaris. }}$

695 

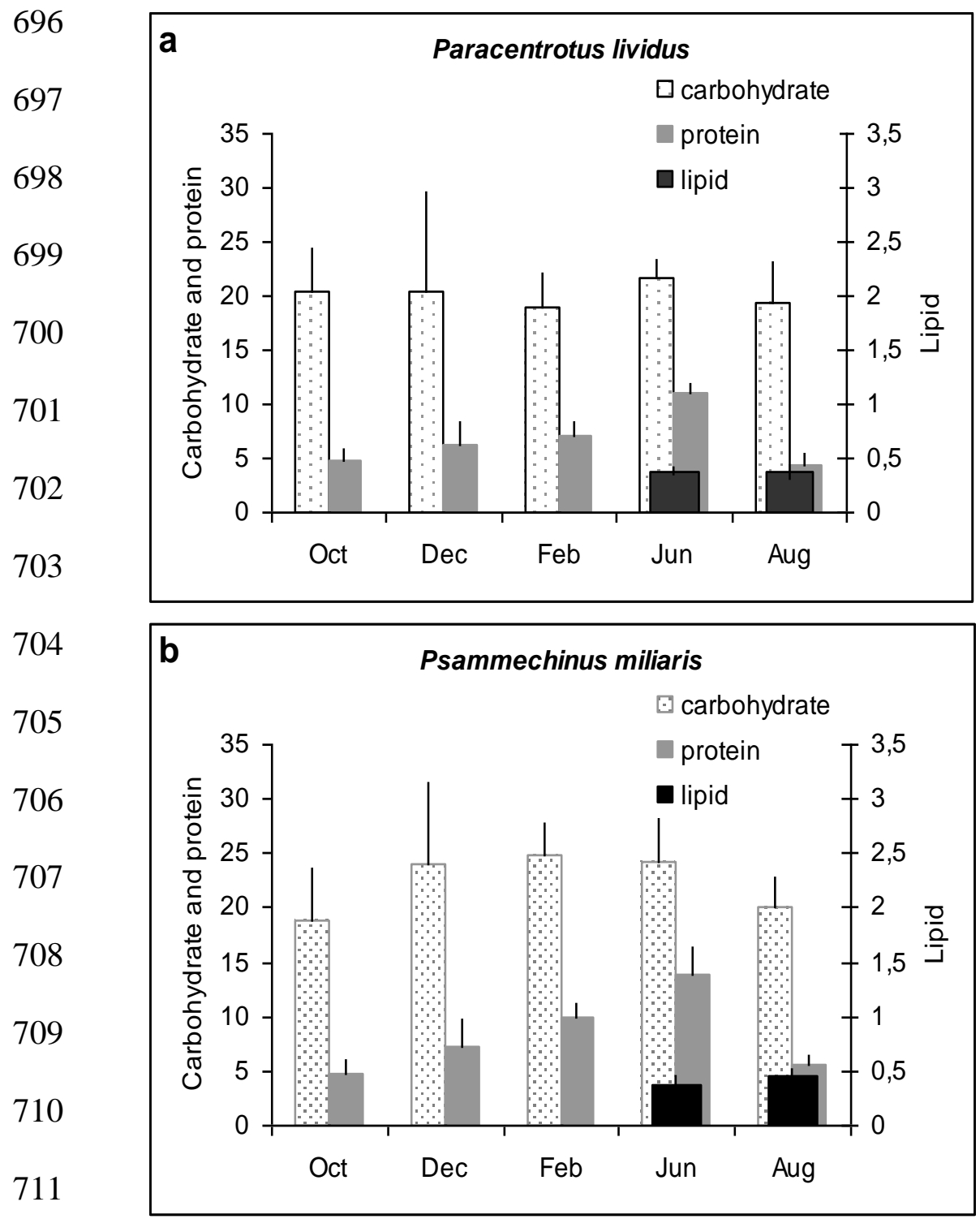

712 Fig. 7 Seasonal changes in the absorption rate of the sea urchins fed

713 Palmaria palmata in term of proteins, carbohydrates and lipids (in mg DW d

$714{ }^{1}$ urchin $\left.^{-1}\right)(+$ SD). a : $\underline{\text { Paracentrotus lividus }} ; \mathrm{b}$ : $\underline{\text { Psammechinus miliaris }}$. 


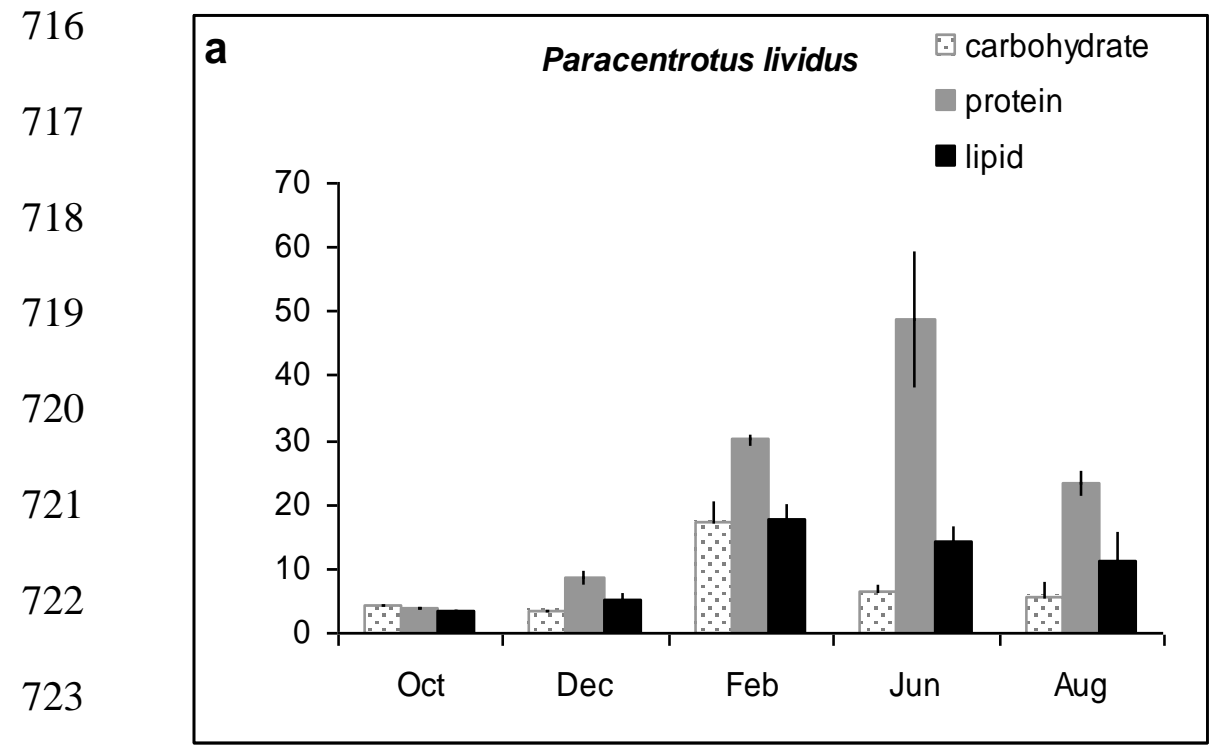

724

725

726

727

728

729

730

731

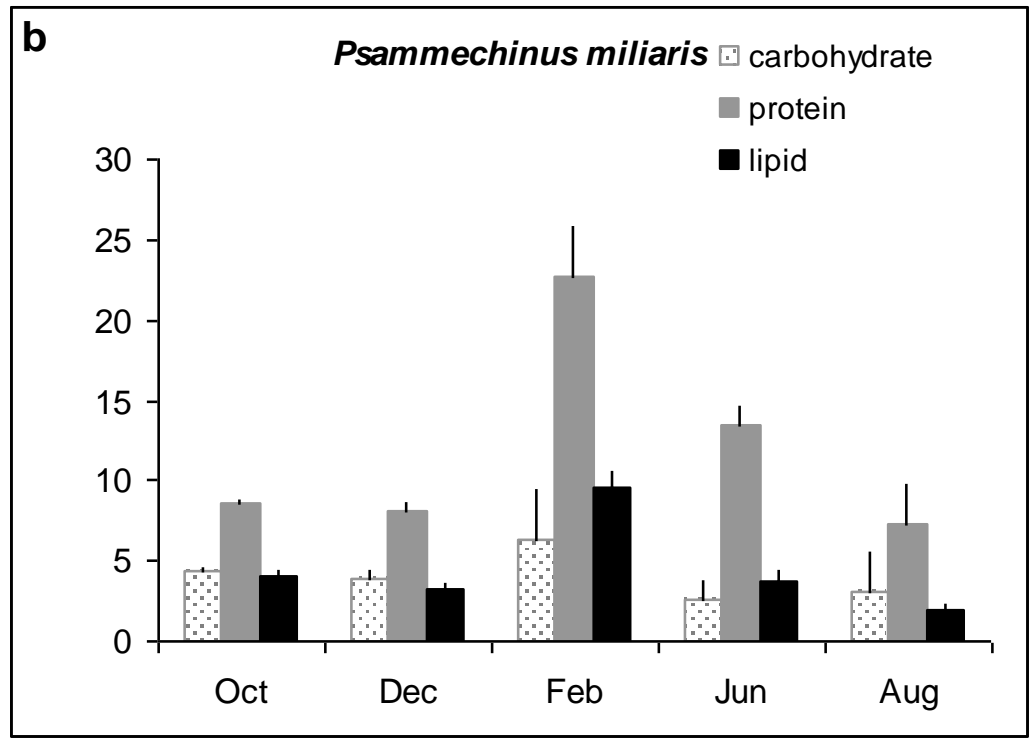

732

733 Fig. 8 Seasonal changes in the estimated composition of the gonad of the

734 sea urchins fed Palmaria palmata (in mg DW) (+SD). a : $\underline{\text { Paracentrotus }}$

735 lividus; $\mathrm{b}$ : $\underline{\text { Psammechinus miliaris. }}$

736

737

738

REFERENCES

739 


\section{$740 \quad$ References}

741

742 Akiyama, T., Unuma, T., Yamamoto, T., 2001. Optimum protein level in a

743 purified diet for young red sea urchin Pseudocentrotus depressus. Fish. Sci.

$744 \quad 67,361-363$.

745 Allain, J.Y., 1975. Structure des populations de Paracentrotus lividus

746 (Lamarck) (Echinodermata, Echinoidea) soumises à la pêche sur les côtes

747 Nord de Bretagne. Rev. Trav. Inst. Pêches Marit. 39, 171-212.

748 Basuyaux, O., Blin, J.L., 1998. Use of maize as a food source for sea urchin

749 in a recirculating rearing system. Aquat. Int. 6, 233-247.

750 Bligh, E.G., Dyer, W.J., 1959. A rapid method of total lipid extraction and 751 purification. Can. J. Biochem. Physiol. 37, 911-917.

752 Boudouresque, C.F., Verlaque, M., 2001. Ecology of Paracentrotus lividus.

753 In: Lawrence, J.M. (Ed.), Edible Sea Urchins: biology and ecology. Elsevier

754 Science Publishers B.V., Amsterdam, pp. 177-216.

755 Byrne, M., 1990. Annual reproductive cycles of the commercial sea urchin

756 Paracentrotus lividus from an exposed intertidal and a sheltered subtidal

757 habitat on the west coast of Ireland. Mar. Biol. 104, 275-289.

758

759 Chapman, A.R.O., Craige, J.S., 1977. Seasonal growth in Laminaria

760 longicruris: relations with dissolved inorganic nutrients and internal reserves

761 of N. Mar. Biol. 40, 197-205. 
763 De Ridder, C., Lawrence, J.M., 1982. Food and feeding mechanisms:

764 Echinoidea. In: Jangoux, M., Lawrence, J.M., (Eds), Echinoderm Nutrition.

765 A.A. Balkema Publishers, Rotterdam, pp.57-115.

766

767 Dominique, F., 1973. Contribution à l'étude du cycle annuel de 768 reproduction de deux espèces d'échinoides (Echinodermata) des côtes de

769 Bretagne. B. SC. Thesis, Université Libre de Bruxelles, Belgique 770

771 Dubois, M., Gilles, K.A., Hamilton, J.K, Reber, P.A., Smith, F., 1956.

772 Colorimetric method for determination of sugar and related substance. Anal.

773 Chem. 28, 350-356.

774

775 Fenaux, L., Malara, G., Cellario, C., Charra, R., Palazzoli, T., 1977.

776 Evolution des constituants biochimiques des principaux compartiments de

777 l'oursin Arbacia lixula (L.) au cours d'un cycle sexuel et effets d'un jeûne de

778 courte durée au cours de la maturation sexuelle. J. Exp. Mar. Biol. Ecol. 28, $779 \quad 17-30$.

780

781 Fernandez, C., 1996. Croissance et nutrition de Paracentrotus lividus dans le

782 cadre d'un projet aquacole avec alimentation artificielle. Thèse de doctorat 783 de l’Université de Corse, France.

785 Fernandez, C., 1998. Seasonal changes in the biochemical composition of 786 the edible sea urchin Paracentrotus lividus (Echinodermata : Echinoidea) in 787 a lagoonal environment. Mar. Ecol. 1998; 19(1), 1-11. 
789 Fleurence, J., 1999. Seaweed proteins: biochemical, nutritional aspects and

790 potential uses. Trends Food Sci. Technol. 10, 25-28.

791

792 Frantzis, A., Grémare, A., 1992. Ingestion, absorption, and growth rates of 793 Paracentrotus lividus (Echinodermata : Echinoidea) fed different 794 macrophytes. Mar. Ecol. Prog. Ser. 95, 169-183.

795

796 Fuji, A., 1967. Ecological studies on the growth and food consumption of 797 Japanese common littoral sea urchin, Strongylocentrotus intermedius. Mem. 798 Fac. Fish., Hokkaido Univ. 15, 83-160.

799

800 Galland-Irmouli, A-V., Fleurence, J., Lamghari, R., Luçon, M., Rouxel, C.,

801 Barbaroux, O., Bronowicki, J.P., Villaume, C., Guéant, J.L., 1999.

802 Nutritional value of proteins from edible seaweed Palmaria palmata (Dulse).

803 J. Nutr. Biochem. 10, 353-359.

804

805 Guillou, M., Grall, J., Connan, S., 2002. Can low sea urchin densities

806 control macro-epiphytic biomass in a north-east Atlantic maerl bed

807 ecosystem (Bay of Brest, France)? J. Mar. Biol. Ass. U. K. 82, 867-876.

808

809 Hagen Rødde, R.S., Vårum, K.M., Larsen, B.A., Myklestad, S.M., 2004.

810 Seasonal and geographical variation in the chemical composition of the red

811 alga Palmaria palmata (L.) Kuntze. Bot. Mar. 47, 125-133. 
813 Indergaard, M., Minsaas, J., 1991. Animal and human nutrition. In Guiry,

814 M., Blunden, G. (Eds.), Seaweed resources in Europe: uses and potential. J.

815 Wiley and Sons Publishers, New-York, pp. 21-64.

816

817 Kelly, M.S., 2000. The reproductive cycle of the sea urchin Psammechinus

$818 \underline{\text { miliaris }}$ (Echinodermata : Echinoidea) in a Scottish sea loch. J. Mar. Biol.

819 Ass. U. K. 80, 909-919.

820

821 Kelly, M.S., 2001. Environmental parameters controlling gametogenesis in

822 the echinoid Psammechinus miliaris. J. Exp. Mar. Biol. Ecol. 12, 45-64.

824 Kelly, M.S., Cook, E.J., 2001. The ecology of Psammechinus miliaris. In:

825 Lawrence, J.M. (Ed.), Edible Sea Urchins: biology and ecology. Elsevier

826 Science Publishers B.V., Amsterdam, pp. 217-224.

828 Lahaye, M., 1991. Marine algae as source of fibres: determination of soluble

829 and insoluble dietary fibers contents in some "sea vegetables". J. Sci. Food 830 Agric. 54, 587-594.

831

832 Lares, M.T., McClintock, J.B., 1991. The effects of temperature on the 833 survival, organismal activity, nutrition, growth, and reproduction of the 834 carnivorous, tropical sea urchin Eucidaris tribuloides. Mar. Behav. Physiol. 835 19(2), 75-96.

836 
837 Larson, B.R., Vadas, R.L., Keser, M., 1980. Feeding and nutritional ecology

838 of the sea urchin Strongylocentrotus drobachiensis in Maine, USA. Mar.

839 Biol. 59, 49-62.

840

841 Le Gall, L., 2002. Etudes biologiques, biochimiques et cellulaires de

842 Palmaria palmata (Rhodophyta); applications biotechnologiques à

843 l'aquaculture. Thèse de doctorat de l'Université de Caen, France.

844

845 Le Gall, P., 1989. L'échinoculture. Technique et documentation. Lavoisier,

846 Paris (France). pp.467-491.

847

848 Le Gall, P., Bucaille, D., Dutot, P., 1989. Résistance aux variations de

849 salinité chez Paracentrotus et Psammechinus. Vie mar. HS10, 83-84.

850

851 Le Gall, P., Bucaille, D., Grassin, J.B., 1990. Influence de la température sur

852 la croissance de deux oursins comestibles, Paracentrotus lividus et

853 Psammechinus miliaris. In: De Ridder, C, Dubois, P., Lahaye, M.C.,

854 Jangoux, M. (eds). Echinoderm Research. Balkema publishers, Rotterdam, $855 \quad$ pp183-188.

856

857 Lemire, M., Himmelman, J-H., 1996. Relation of food preference to fitness 858 for the green sea urchin, Strongylocentrotus droebachiensis. Mar. Biol. 127

859 (1), 73-78.

860 
861 Lowe, E.F., Lawrence, J.M., 1976. Absorption efficiencies of Lytechinus

862 variegatus (Lamarck) (Echinodermata: Echinoidea) for selected marine

863 plants. J. Exp. Mar. Biol. Ecol. 21, 223-234.

864

865 Lowry, O.H., Rosebrough, J.N, Farr, A.L,. Randall, R.J., 1951. Protein

866 measurement with folin reagent. J. Biol. Chem. 193, 265-275.

867

868 Martinez, B., Rico,. J.M., 2002. Seasonal variation of P content and major N

869 pools in Palmaria palmata (Rhodophyta). J. Physiol. 58, 1082-1089.

870

871 Monteiro-Torreiro, M.F., Garcia-Martinez, P., 2003. Seasonal changes in

872 the biochemical composition of body components of the sea urchin,

873 Paracentrotus lividus, in Lorbé (Galicia, north-western Spain). J. Mar. Biol.

874 Ass. U.K. 83, 575-581.

875

876 Morgan, K.C., Wright, J.L.C., Simpson, F.J., 1980. Review of chemical

877 constituents of the red alga Palmaria palmata (Dulse). Econ. Bot. 34(1), 2787850

879

880 Morgan, K.C., Simpson, F.J., 1981. Cultivation of Palmaria palmata. Effect

881 of light intensity and nitrate supply on growth and chemical composition.

882 Bot. Mar. 24, 547-552.

883 
884 Otero-Villanueva, M., Kelly, M.S., Burnell, G., 2004. How diet influences

885 energy partitioning in the regular echinoid Psammechinus miliaris;

886 constructing an energy budget. J. Exp. Mar. Biol. Ecol. 304, 159-181.

887

888 Pearce, C.M., Daggett, T.L., Robinson, S.M.C., 2003. Effects of starch type, 889 macroalgal meal source, and $\beta$-carotene on gonad yield and quality of the

890 green sea urchin, Strongylocentrotus droebachiensis (Müller), fed prepared 891 diets. J. Shelfish Res. 17, 1591-1595.

892

893 Rouxel, C., Bonnabeze, E., Daniel, A, Jerome, M., Etienne, M., Fleurence,

894 J., 2001. Identification by SDS PAGE of green seaweeds (Ulva and

895 Enteromorpha) used in the food industry. J. Appl. Ecol. 13 (3), 215-219.

896

897 Sánchez-Machado, D.I., López-Cervantes, J., López-Hernández, J., Paseiro-

898 Losada, P., 2004. Fatty acids, total lipid, protein and ash contents of 899 processes edible seaweeds. Food Chem. 85, 439-444.

900

901 Southward, A., Southward, E., 1975. Endangered urchins. New Sci. 902 66(944), 70-72.

903

904 Spirlet,, C., Grosjean, P., Jangoux, M., 1998. Reproductive cycle of the 905 echinoid Paracentrotus lividus: analysis by means of maturity index. Invert. 906 Reprod. Dev. 34, 69-81.

907 
908 Spirlet, C., Grosjean, P., Jangoux, M., 2000. Optimization of gonad growth

909 by manipulation of temperature and photoperiod in cultivated sea urchins,

910 Paracentrotus lividus (Lamarck) (Echinodermata). Aquaculture 185, 85-99.

911

912 Strickland, J., Parsons, T., 1972. A practical handbook of seawater analysis.

913 Fish. Res. Bd. Can. Bull.167, pp.1-310.

914

915 Vadas, R.L., Beal, B., Dowling, T., Fegley, J.C., 2000. Experimental field

916 tests of natural diets on gonad index and quality in the green sea urchin,

917 Strongylocentrotus droebachiensis : a case for rapid summer production in

918 post-spawned animals. Aquaculture 182, 115-135.

919

920 Watts, S.A., Boettger, A., McClintock J.B., Lawrence, J.M., 1998. Gonad

921 production in the sea urchin Lytechinus variegatus (Lamarck) fed prepared

922 diets. J. Shellfish Res. 15(5), 1591-1595.

923

924 